\title{
IMPLEMENTASI KEPEMIMPINAN TRANSFORMASIONAL KEPALA SEKOLAH DALAM MENINGKATKAN MUTU SEKOLAH DI SD KANISIUS SENGKAN KABUPATEN SLEMAN
}

\author{
Tukiman, Cepi S. Abdul Jabar \\ Kepala Sekolah SMA St. Antonius Jakarta Timur, \\ Program Pascasarjana Universitas Negeri Yogyakarta \\ marktukiman@gmail.com, cepi_safruddin@uny.ac.id
}

\begin{abstract}
Abstrak
Penelitian ini bertujuan untuk mengungkapkan implementasi kepemimpinan transformasional kepala sekolah dalam meningkatkan mutu sekolah SD Kanisius Sengkan, Kabupaten Sleman. Penelitian ini merupakan penelitian kualitatif dengan jenis penelitian studi kasus. Pengumpulan data menggunakan metode kajian dokumen, observasi, dan wawancara. Analisis data menggunakan analisis model interaktif dari Miles dan Huberman yang meliputi empat tahap analisis yaitu: pengumpulan data, reduksi data, penyajian data, dan penarikan kesimpulan. Hasil penelitian menunjukkan bahwa kepemimpinan transformasional kepala sekolah SD Kanisius Sengkan mampu menciptakan perubahan dan membawa SD Kanisius mencapai prestasi yang baik. Kepala sekolah menjadi tokoh panutan yang dihormati, dihargai, dan dipercaya. Kepala sekolah mampu membangun semangat kebersamaan dan kedisiplinan serta memotivasi para guru dan karyawan untuk bekerja secara optimal. Kepala sekolah berani melakukan perubahan melalui tindakan-tindakan yang kreatif dan inovatif. Akhirnya kepala sekolah mampu membangun kesadaran berorganisasi pada para guru dan karyawan dengan mengembangkan sikap rasa memiliki dan rasa bertanggung jawab untuk meraih prestasi setinggi-tingginya.
\end{abstract}

Kata kunci: kepala sekolah, kepemimpian transformasional, mutu sekolah.

\section{TRANSFORMATIONAL LEADERSHIP IMPLEMENTATION OF IMPROVING QUALITY OF PRINCIPAL SCHOOLS IN THE DISTRICT SD KANISIUS SENGKAN SLEMAN}

\begin{abstract}
This research aims to reveal the implementations of principal's transformasional leadership in improving the school's quality of SD Kanisius Sengkan, Sleman Regency. The research is a qualitative case study. It was conducted in SD Kanisius Sengkan, Sleman Regency. The subjects included the principal, the chairman of the committee, teachers, employees, students, and parents. The techniques of data collection used document review, observation and interviews. The data analysis used an interactive analysis model of Miles and Huberman which includes four stages of analysis, namely: data collection, data reduction, data display and conclusion drawing. The results show that the principal's transformasional leadership is able to create a change and bring SD Kanisius to achieve a good performance. The principal becomes the role model who is admired, respected, and trusted. He is able to build a team spirit and discipline and motivate the teachers and employees to work optimally. He makes changes through the creative and innovative actions. He pays attention and reward to the teachers and employees. He is finally able to build the organizational awareness of the teachers and employees to develop a sense of belonging and sense of responsibility to achieve the highest achievement.
\end{abstract}

Keywords: principal, transformational leadership, school quality. 


\section{Pendahuluan}

Seorang filsuf Yunani, Plato pernah mengatakan; "Jika Anda bertanya apa manfaat pendidikan, maka jawabannya sederhana; pendidikan membuat orang menjadi lebih baik dan orang baik tentu berperilaku mulia" (Fatchul Mu'in, 2011: 21). Dari ungkapan Plato tersebut betapa pentingnya pendidikan. Pendidikan dapat membentuk manusia menjadi lebih baik, dengan demikian diharapkan dapat berperilaku baik atau mulia.

Pentingnya pendidikan juga dilihat oleh para pendiri bangsa Indonesia. Dalam Undang-Undang Dasar 1945, khususnya pasal 31 ayat (1) dengan sangat jelas dinyatakan "Setiap warga negara berhak mendapatkan pendidikan". Bahkan negara mewajibkan setiap warganya memperoleh pendidikan, (2) "Setiap warga negara wajib mengikuti pendidikan dasar dan pemerintah wajib membiayainya". Tidak cukup hanya mewajibkan, negara juga secara serius mengusahakan biaya pendidikan, (4) "Negara memprioritaskan anggaran pendidikan sekurang-kurangnya $20 \%$ dari anggaran pendapatan dan belanja negara serta dari anggaran pendapatan dan belanja daerah untuk memenuhi kebutuhan penyelenggaraan pendidikan nasional". Dari dasar negara ini, sangat jelas bahwa pemerintah secara serius menempatkan pendidikan sebagai program yang utama dalam penyelenggaraan negara.

Keseriusan pemerintah untuk meningkatkan mutu dan pemerataan pendidikan juga nampak dalam kebijakan yang dikeluarkan dalam bentuk undangundang. Undang-Undang No. 22 tahun 1999 tentang Otonomi Pemerintah Daerah dan Undang-Undang No. 25 tahun 1999 tentang Perimbangan Keuangan antara Pemerintah Pusat dan Daerah telah membawa dampak yang luas dalam penyelenggaraan pemerintahan daerah, termasuk bidang pendidikan. Bila sebelumnya manajemen pendidikan merupakan wewenang pemerintah pusat, dengan berlakunya undang-undang tersebut kewenangan pengelolaan pendidikan dialihkan ke pemerintah kabupaten atau kota.
Salah satu pilar penting dalam proses pendidikan formal adalah peran kepala sekolah dalam menjalankan tugas dan fungsinya. Kepemimpinan kepala sekolah menjadi ujung tombak bagi keberhasilan proses pendidikan di sekolah. Studi tentang keberhasilan kepemimpinan kepala sekolah menunjukkan bahwa kepala sekolah adalah seorang yang menentukan titik pusat dan irama sekolah. Bahkan Wahjosumidjo (2011: 82). menyebutkan "keberhasilan sekolah adalah keberhasilan kepala sekolah".

Tanggung jawab kepala sekolah menjadi semakin berat ketika ketentuan otonomi daerah yang dilandasi oleh Undang-Undang No. 22 tahun 1999 diberlakukan. Dengan undang-undang ini peningkatan efisiensi pengelolaan pendidikan mengarah pada pengelolaan berbasis sekolah atau yang lebih dikenal dengan sebutan Manajemen Berbasis Sekolah (MBS). Pengelolaan berbasis sekolah memberikan kepercayaan yang luas kepada sekolah untuk mengoptimalkan sumber daya yang tersedia di sekolah bagi tercapainya tujuan pendidikan yang diharapkan. Hal senada diungkapkan oleh Mulyasa (2011: 24), "Kepala sekolah merupakan salah satu komponen pendidikan yang paling berperan dalam meningkatkan kualitas pendidikan". Dalam rangka melaksanakan pendidikan yang berbasis sekolah, kepala sekolah, sebagai pemimpin dituntut memiliki kemampuan mengelola sekolah dengan baik. Bagi kepala sekolah, Manajemen Berbasis Sekolah merupakan tantangan baru bagi kepemimpinannya.

Selain tantangan yang ditimbulkan dari diberlakukannya undang-undang otonomi daerah, kepala sekolah juga harus menghadapi tantangan lain yang tidak kalah seriusnya yaitu arus globalisasi. Arus kehidupan global telah membuat kehidupan ini bergerak dan berubah semakin cepat dan kompetitif. Semua bidang kehidupan mengalami pergeseran dan tantangan, tak terkecuali bidang pendidikan. Sekolah sebagai lembaga pendidikan menghadapi tantangan yang serius untuk mampu mengikuti gerak perubahan global 
tersebut. Karena kalau sekolah tidak mampu menjawab tantangan jaman ini, maka sekolah akan mengalami kehancuran, karena dianggap tidak mampu menjawab tantangan jaman dan mengatasi kekinian yang terjadi. Maka sangat dibutuhkan seorang pemimpin transformatif. Seorang kepala yang berani mengambil resiko dan menjadi agen perubahan (agent of change). Perubahan ke arah yang lebih baik. Starratt (2007) menyebutnya sebagai kepemimpinan kepala sekolah yang visioner.

Sekolah Dasar Kanisius Sengkan yang terletak di $\mathrm{Jl}$. Kaliurang $\mathrm{Km} 7$ terpanggil juga untuk ikut ambil bagian dalam proses pendidikan. Pendidikan yang bertujuan mempersiapkan generasi muda menjadi generasi yang memiliki karakter baik. Namun pertengahan tahun 1990-an SD Kanisius Sengkan mengalami krisis yang cukup serius. Krisis ini sangat jelas dapat dilihat dari jumlah siswa yang masuk semakin menurun. Tahun ajaran 1998/1999 krisis mencapai titik terendah dengan jumlah siswa keseluruhan hanya 99 anak (Yayasan Pendidikan Kanisius, 2010). Jumlah siswa yang sedikit membuat motivasi kerja guru menurun, akibatnya kegiatan belajar-mengajar berjalan hanya mengalir saja. Kinerja guru yang kurang optimal tersebut berpengaruh pada prestasi siswa. Tidak ada lagi prestasi siswa yang dapat dibanggakan. Bahkan tak jarang kepala sekolah memulangkan anakanak lebih awal tanpa alasan yang dapat dipertanggungjawabkan.

Selain itu sarana dan prasarana pendidikan juga sudah mulai usang. Ruang kelas kurang kondusif untuk melaksanakan kegiatan belajar dan mengajar karena beberapa bagian dinding rusak. Kendati demikian belum ada usaha dari yayasan untuk memperbaikinya. Lingkungan sekolah kurang rapi bahkan terkesan kumuh sehingga kurang kondusif untuk proses belajar dan mengajar. Kondisi fisik sekolah yang kurang menarik ini kiranya juga menjadi penyebab banyak orang tua tidak tertarik untuk menyekolahkan anaknya di SD Kanisius Sengkan.
Situasi krisis ini diperparah lagi dengan kinerja guru yang kurang optimal dan profesional. Guru-guru sebagain besar sudah berusia lanjut namun belum ada regenerasi. Sementara itu relasi antar guru kurang terbangun dengan baik bahkan relasi antara guru dengan kepala sekolah juga kurang baik. Kepala sekolah kurang mampu memimpin dengan baik sehingga banyak hal justeru dikendalikan oleh guru. Kinerja guru sering disibukan dengan urusan keuangan sekolah karena keuangan sekolah; seperti SPP dan tabungan anak dikelola oleh masing-masing guru kelas. Bahkan ada sebagian guru yang dengan mudah meninggalkan sekolah jika tidak ada jam mengajar di kelas.

Situasi krisis tersebut di atas akhirnya membuat pihak Yayasan Kanisius memasukkan SD Kanisius Sengkan sebagai sekolah dasar yang masuk dalam daftar tunggu. Artinya setiap saat SD Kanisius Sengkan siap untuk ditutup karena jumlah siswa keseluruhannya kurang dari 100 siswa. Namun keputusan yayasan ini tidak disetujui oleh komite sekolah dan masyarakat Sengkan, yang sejak awal menginginkan adanya sekolah dasar di desa Sengkan. Komite sekolah dan masyarakat tetap berjuang agar SD Kanisus Sengkan tetap berdiri.

Awal tahun 2006 Yayasan Pendidikan Kanisius Cabang Yogyakarta mengangkat kepala sekolah baru untuk SD Kanisius Sengkan. Kepala sekolah baru ini diharapkan mampu mengangkat kembali prestasi SD Kanisius Sengkan. Kepala sekolah diharapkan mampu mencari terobosanterobosan baru yang kreatif dan inovatif bagi pengembangan sekolah. Dari harapan ini kepala sekolah menjadi tumpuan pengharapan untuk perubahan ke arah yang lebih baik. Atau dengan kata lain seperti yang ditegaskan oleh Wahjosumidjo (2000: 82) "keberhasilan sekolah adalah keberhasilan kepala sekolah".

Tujuan penelitian ini adalah 1) Menggali nilai-nilai luhur yang mendorong kepala sekolah SD Kanisius Sengkan untuk dapat memimpin dengan baik. 2). Menjelaskan usaha-usaha kepala sekolah dalam 
menumbuhkan sikap percaya diri dan saling percaya dalam diri para guru dan karyawan. 3) Menjelaskan upaya kepala sekolah dalam membangun motivasi, komitmen dan antusiasme para guru dan karyawan untuk bekerja secara optimal. 4) Menjelaskan usaha-usaha kepala sekolah dalam melakukan perubahan melalui ideide kreatif dan inovatif. 5) Menjelaskan usaha-usaha kepala sekolah dalam memberikan perhatian dan penghargaan kepada para guru dan karyawan. 6) Menggali upaya kepala sekolah dalam meningkatkan mutu sekolah.

Hasil penelitian ini diharapkan memberikan kontribusi teoretis dan praktis. Secara teoretis, hasil penelitian diharapkan memberikan sumbangsih terhadap pengembangan ilmu manajemen pendidikan tentang pentingnya peran kepemimpinan transfomasional kepala sekolah sebagai penentu motivasi kerja para guru dan karyawan sekolah. Selain itu juga memberikan rangsangan dalam melakukan penelitian lanjut tentang faktor-faktor yang mempengaruhi motivasi kerja para pendidik dalam rangka mengembangkan ilmu manajemen pendidikan.

Secara praktis hasil penelitian diharapkan menjadi bahan informasi bagi para pengelola pendidikan untuk dapat belajar dari pengalaman SD Kanisius Sengkan dalam menghadapi sebuah tantangan. Bahwa pola kepemimpian transformatif yang dijalankan oleh kepala sekolah SD Kanisius Sengkan dapat menyelamatkan sekolah itu dari kehancuran. Pola kepemimpinan itu terutama melalui keteladanan hidup kepala sekolah sendiri.

Fokus penelitian atau masalah yang dikaji dalam penelitian ini adalah kepemimpinan transformasional kepala sekolah dalam meningkatkan mutu sekolah SD Kanisius Sengkan. Untuk dapat mengetahui implementasi kepemimpinan transformatif kepala sekolah tersebut digali melalui pertanyaan penelitan sebagai berikut:

1. Nilai-nilai apa yang diyakini dan diperjuangkan oleh kepala sekolah untuk membangun SDKanisius Sengkan?
2. Bagaimana kepala sekolah membangun rasa saling percaya di antara para guru dan karyawan?

3. Bagaimana kepala sekola membangun motivasi dalam diri para guru dan karyawan untuk bekerja optimal?

4. Bagaimana kepala sekolah menggali ide-ide kreatif dan inovatif untuk memecahkan masalah yang dihadapi sekolah?

5. Bagaimana kepala sekolah memberikan perhatian dan penghargaan kepada para guru dan karyawan?

6. Bagaimana kepala sekolah meningkatkan mutu sekolah?

Menurut Anderson perilaku kepemimpinan transformasional adalah kepemimpinan yang memiliki visi, perencanaan, komunikasi, dan tindakan yang kreatif, yang berdampak positif pada kelompok dalam sebuah keyakinan nilai yang jelas untuk mencapai tujuan yang telah ditetapkan (Usman, 2008: 313). Dalam hal ini pemimpin transformasional sebagai agen perubahan positif, yang antara lain dapat mengubah lingkungan, organisasi, kelompok maupun pribadi-pribadi.

Bass dan Riggio (2006) menunjukkan empat komponen pokok kepemimpinan transformasional. Keempat komponen pokok itu adalah:

1) Idealized influence; merupakan perilaku pemimpin yang menghasilkan rasa hormat (respect) dan rasa percaya diri (trust) dari orang-orang yang dipimpinnya. Idealized influence mengandung makna saling berbagi resiko melalui pertimbangan-pertimbangan etis akan kebutuhan orang yang dipimpin di atas kebutuhan pribadi. "Transformational leaders behave in ways that allow them to serve as role models for their followers. The leaders are admired, respected, and trusted" (Bass \& Riggio, 2006: $6)$.

2) Inspirational motivation; pada dimensi ini pemimpin transformasional mampu memberi motivasi dan menginspirasi para pengikutnya melalui tantangan dan pemberian makna dalam pekerjaan mereka. Pemimpin transformasional di- 
gambarkan sebagai pemimpin yang mampu mengartikulasikan pengharapan yang jelas terhadap prestasi pengikut, mendemonstrasikan komitmennya terhadap seluruh tujuan organisasi, dan mampu menggugah spirit tim dalam organisasi dengan cara menumbuhkan antusiasme dan optimisme. "Transformational leaders behave in ways that motivate and inspire those around them by providing meaning and challenge to their followers' work" (Bass \& Riggio, 2006: 6).

3) Intellectual stimulation; pada dimensi ini pemimpin transformasional memberikan dorongan kepada para pengikutnya untuk lebih inovatif dan kreatif. Pemimpin transformasional mampu menumbuhkan ide-ide baru, memberikan solusi yang kreatif terhadap permasalahan-permasalahan yang dihadapi pengikutnya, dan memberikan motivasi kepada pengikut untuk mencari pendekatan-pendekatan yang baru dalam melaksanakan tugas-tugas organisasi. "Transformational leaders stimulate their followers efforts to be innovative and creative by questioning assumptions, reframing problems, and approaching old situations in new ways" (Bass \& Riggio, 2006: 7).

4). Individualized consideration; pada dimensi ini pemimpin transformasional mampu memberi perhatian yang besar kepada masing-masing pengikut. Pemimpin transformasional digambarkan sebagai seorang pemimpin yang mau mendengarkan dengan penuh perhatian masukan- masukan para pengikutnya dan secara khusus mau memperhatikan kebutuhan-kebutuhan pengikut akan pengembangan dirinya. "Transformational leaders pay special attention to each individual follower's needs for achievement and growth by acting as a coach or mentor" (Bass \& Riggio, 2006: 7).

Sadler memaknai kepemimpinan transformasioal sebagai proses penanaman nilai oleh pemimpin kepada bawahannya. Sadler (1997: 42) mengatakan "The transformational leadership is the process of engaging the commitment of employees in the context of shared values and shared vision". Dalam definisi ini ada empat hal pokok yaitu; process, commitment, shared values dan shared vision. Dari definisi Sadler ini menjadi jelas bahwa kepemimpinan transformasional merupkan sebuah proses (process), yaitu proses menuju ke arah yang lebih baik. Atau proses penanaman nilai-nilai kebaikan oleh pemimpin kepada bawahannya. Proses penanaman nilai itu membutuhkan komitmen (commitment). Komitmen merupakan sikap atau rasa tanggung jawab untuk melaksanakan kesepakatan yang telah janjikan. Sementara itu nilai-nilai yang ditanamkan adalah nilai-nilai kebaikan dan visi organisasi.

Sementara itu Simic menyatakan bahwa kepemimpinan transformasional menjadi kunci suksesnya perubahan manajemen organisasi. Dalam artikelnya yang berjudul "Transformational leadership-the key to successful management of transformational organizational changes" Simic menegaskan bahwa "Transformational leadership represents the essetial quality for successful managment of transformational organizational changes".(Simic,1999: http://facta.junis.ni.ac.rs leao/. dambil tgl. 25 Mei 2013). Selanjutnya Wuradji (2008: 50) menegaskan "menurut teori transformasional, untuk menjadi pemimpin yang sukses dia harus membangkitkan komitmen pengikutnya untuk membangun nilai-nilai organisasi atas kesadarannya sendiri".

Di sekolah, kepala sekolah memiliki peran yang sangat penting dalam proses meningkatkan mutu sekolah. Mulyasa (2011:159) menegaskan "Gaya kepemimpinan kepala sekolah berpengaruh terhadap kinerja tenaga kependidikan di sekolah untuk meningkatkan produktivitas kerja demi mencapai tujuan dan mewujudkan visi menjadi aksi" Sementara itu Sergiovanni menyatakan bahwa seorang kepala sekolah yang ideal harus menyadari tugas-tugas utama sebagai administrator. "They consider to be the essenstial roles and tasks of administrators. Planning, organizing, leading and controlling" (Sergiovanni, 1991: 17). Dengan demikian jelas bahwa di sekolah, kepala sekolah adalah pemimpin dalam gerakan mutu. 
Arcaro (2007: 10) menegaskan bahwa untuk menuju sekolah bermutu harus diterapkan Manjemen Mutu Terpadu (MMT). Masih menurut Arcaro Manajemen Mutu Terpadu dapat membantu pendidikan menyesuaikan diri dengan keterbatasan dana dan waktu. Selanjutnya Arcaro (2007: 10-11)menegaskan:

"Transformasi menuju sekolah bermutu terpadu diawali dengan mengadopsi dedikasi bersama terhadap mutu oleh dewan sekolah, administrator, staf, siswa, guru dan komunitas. Prosesnya diawali dengan mengembangkan visi dan misi mutu untuk wilayah dan setiap sekolah serta departemen dalam wilayah tersebut."

Sementara itu dalam Peraturan Pemerintah Tahun 2005 Nomor 15 disebutkan Standar Nasional Pendidikan yang mengacu pada sekolah yang bermutu. Standar Nasional Pendidikan tersebut meliputi: standar kompetensi lulusan, standar isi, standar proses, standar pendidik dan tenaga kependidikan, standar sarana dan prasarana, standar pengelolaan, standar pembiayaan, standar penilaian. Yayasan Pendidikan Kanisius (2008: 39) mengembangkan Paradigma Pedagogi Reflektif (PPR) sebagai alternatif solusi menuju pendidikan sekolah yang bermutu. Paradigma Pedagogi Reflektif merupakan pola pikir dalam menumbuhkembangkan pribadi siswa menjadi pribadi yang kritis dan reflektif. Ada lima unsur penting dalam model pendidikan PPR yaitu; konteks, pengalaman, refeksi, aksi dan evaluasi.

Gambaran pembinaan siswa melalui PPR untuk menuju sekolah yang bermutu secara singkat adalah sebagai berikut:

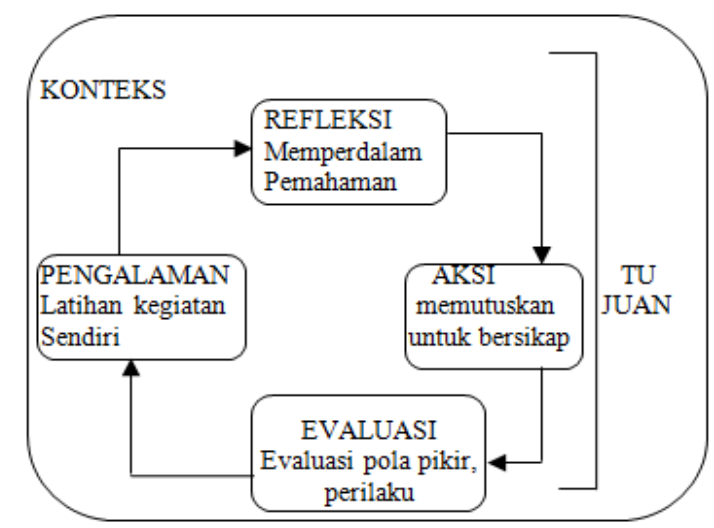

Gambar 1.
Pola pembinaan melalui Paradigma Pedagogi Reflektif dapat dijelaskan sebagai berikut:

Konteks; konteks untuk menumbuhkembangkan pendidikan yang bermutu antara lain: a) Wacana tentang nilai-nilai yang akan ditumbuhkembangkan. Dalam hal ini semua anggota komunitas, guru dan siswa menyadari bahwa yang menjadi landasan pengembangan pendidikan bukan aturan, perintah atau sangsi melainkan nilai-nilai kemanusiaan. b) Contoh penghayatan mengenai nilai-nilai yang diperjuangkan, terlebih contoh hidup dan perilaku guru. c) Hubungan yang akrab, saling percaya agar dapat terjalin dialog yang saling terbuka antar guru dan siswa.

Pengalaman; pengalaman untuk menumbuhkembangkan nilai-nilai yang diperjuangkan. Dalam hal ini siswa difasilitasi untuk dapat mengalami secara langsung nilai-nilai yang diperjuangkan. Atau siswa diajak untuk melihat sendiri sebuah perjuangan nilai.

Refleksi; guru memfasilitasi dengan pertanyaan-pertanyaan agar siswa dapat terbantu untuk berefleksi. Dengan pertanyaan refleksif ini siswa diharapkan secara otentik dapat memahami, mendalami dan menyakini temuan nilai yang direfleksikan.

Aksi; guru memfasilitasi siswa dengan pertanyaan aksi agar siswa terbantu untuk bertindak sesuai dengan nilai yang dihasilkan dalam refleksinya.

Evaluasi; setelah pembelajaran guru memberikan evaluasi atas kompetensi siswa dari sisi akademik. Adakah dampak PPR terhadap suasana kelas, cara siswa berbicara, bersikap dan bertindak?

Dari uraian di atas dapat disimpulkan bahwa kepala sekolah sebagai pemimpin gerakan mutu dalam pendidikan diharapkan dapat menjalankan tugas dan fungsinya sebagai kepala secara tepat, namun tugas dan fungsi itu dijalankan tetap dalam koridor visi dan misi sekolah. Salah satu pola pendidikan untuk meningkatkan mutu sekolah adalah Paradigma Pedagogi Reflektif. 


\section{Metode Penelitian}

Jenis penelitian yang digunakan adalah kualitatif dengan menggunakan pendekatan studi kasus. Pendekatan yang digunakan dalam penelitian ini adalah studi kasus. Kasus yang diteliti adalah keberhasilan kepemimpinan kepala sekolah SD Kanisius Sengkan dalam menghadapi masa-masa sulit, dan bahkan mampu menjadikan SD Kanisius Sengkan menjadi salah satu sekolah favorit dengan prestasi yang membanggakan. Pendekatan studi kasus dipilih karena merupakan strategi penelitian di mana di dalamnya peneliti menyelidiki secara cermat suatu peristiwa, aktivitas, baik individu maupun kelompok yang telah atau sedang terjadi.

Penelitian ini dilakukan di SD Kanisius Sengkan, Jl. Kaliurang $\mathrm{Km} \mathrm{7,}$ Kecamatan Depok, Kabupaten Sleman. Sekolah Dasar Kanisius Sengkan dipilih menjadi tempat penelitian karena sekolah ini mampu keluar dari masa-masa sulit, bahkan telah masuk dalam daftar tunggu sekolah yang akan ditutup, namun akhirnya menjadi sekolah favorit berkat kepemimpinan kepala sekolah. Selain itu SD Kanisius Sengkan, dalam proses belajarmengajar tidak hanya menekankan segi kognitif tetapi juga kebudayaan dan cinta lingkungan. Waktu penelitian dilaksanakan pada bulan Februari-April 2013.

Teknik penentuan subjek dalam penelitian ini menggunakan teknik purposive yaitu penentuan subjek berdasarkan pertimbangan tertentu. Pertimbangan tersebut antara lain subjek dipercaya mengetahui dan memahami tentang apa yang hendak diteliti, atau subjek tersebut adalah orang yang memiliki kewenangan dan kekuasaan sehingga mendukung penelitian.

Subjek penelitian yang dipilih adalah kepala sekolah, komite sekolah, para guru dan karyawan, orang tua siswa dan siswasiswi. Subjek penelitian ini sebagai informan yang memberikan informasi kepada peneliti. Peneliti mencari dan mencermati sebanyak mungkin informasi dan kemudian mencari makna dari informasi itu. Dalam hal ini peneliti mengutamakan data langsung atau "first hand" dari para informan. Selain itu peneliti juga melakukan observasi di lapangan dan melakukan kajian dokumentasi yang mendukung dan terkait dengan penelitian.

Sedangkan objek penelitiannya adalah kepemimpinan transformasional kepala sekolah SD Kanisius Sengkan. Bagaimana kepala sekolah menjalankan proses kepemimpinannya untuk keluar dari masamasa sulit dan membawa SD Kanisius Sengkan menjadi sekolah yang berprestasi dengan mutu pendidikan yang baik? Apa usah-usaha kepala sekolah untuk menyelamatkan sekolah dari kehancuran?

Dalam penelitian ini digunakan tiga teknik pengumpalan data yaitu observasi, wawancara dan kajian dokumen. Hal ini sesuai dengan tujuan dan keperluan penelitian yang mencari informasi sebanyak mungkin dari para informan. Peneliti mengumpulkan semua informasi atau data yang diperoleh dari hasil observasi, wawancara dan kajian dokumen menjadi bahan penelitian.

Analisis data dilakukan dengan tujuan agar data yang telah diperoleh dapat lebih bermakna. Analisis data yang digunakan dalam penelitian ini adalah analisis data model interaktif seperti yang dikembangkan oleh Miles dan Huberman (Miles, 1994: 12). Menurut Miles dan Huberman ada empat tahap yang harus dilakukan dalam analisis data yaitu: Pengumpulan data (data collection); merupakan data yang diperoleh melalui hasil observasi, wawancara dan kajian dokumen. Reduksi data (data reduction); reduksi data merupakan pemilihan hal-hal pokok yang sesuai dengan fokus penelitian. Reduksi data diperlukan karena banyaknya data yang diperoleh dari masing-masing informan, yang tidak semua sesuai dan relevan dengan fokus penelitian. Maka data tersebut harus direduksi dan dipilih yang sesuai dan mendukung fokus penelitian. Penyajian data (data display); data yang telah direduksi tersebut selanjutnya disajikan dalam bentuk tulisan yang disusun secara sistematis. Dengan demikian data tersebut lebih mudah dipahami 
maknanya dan mudah pula dalam penarikan kesimpulan. Pernarikan kesimpulan (conclution drawing); proses penarikan kesimpulan sebenarnya sudah dimulai sejak awal penelitian berlangsung, namun penarikan kesimpulan tersebut selalu berkembang sesuai dengan data yang diperoleh dan yang telah dianalisis. Setiap perolehan data baru selalu dianalisis dan disimpulkan, walau agak kabur, namun dalam proses selanjutnya akan semakin jelas dengan semakin banyaknya data yang diperoleh dan yang telah diverifikasi untuk mendukung fokus penelitian.

\section{Hasil Penelitian dan Pembahasan}

Dari hasil penelitian di ketahui bahwa kepala sekolah SD Kanisius Sengkan dalam memimpin sekolah memiliki nilainilai yang diperjuangan. Nilai-nilai tersebut antara lain keterbukaan, kedisiplinan, rasa memiliki, kerjasama, pengabdian, kasih, kesabaran, kejujuran dan menciptakan suasana nyaman. Nilai-nilai tersebut menjadi fondasi untuk membangun kembali SD Kanisius Sengkan yang sedang mengalami krisi. Dengan nilai-nilai tersebut kepala sekolah mempunyai keyakinan bahwa SD Kanisius Sengkan dapat tetap hidup, maju dan berkembang.

Dalam kepemimpinannya kepala sekolah telah membangun rasa percaya diri dan saling percaya antara kepala sekolah dengan para guru dan karyawan. Kepercayaan itu dibangun terutama melalui teladan hidup kepala sekolah sendiri yang dapat dipercaya. Kepala sekolah selalu mengusahakan kesesuaian antara apa yang dikatakan dengan apa yang dilakukan.

Untuk membangun kepercayaan dalam diri para guru dan karyawan, kepala sekolah memberikan kesempatan untuk mengeluarkan pendapat, memberikan kesempatan untuk ikut ambil bagian dalam tugas-tugas dan tanggung jawab, dan juga mengikuti pelatihan-pelatihan. Dengan memberikan kepercayaan kepada para guru dan karyawan maka terciptalah suatu relasi dan komunikasi yang akrab. Ralasi antara kepala sekolah dengan para guru dan karyawan bukan pertama-tama relasi antara atasan dan bawahan melainkan terbangun relasi sebagai teman, sahabat yang berjalan bersama untuk meraih prestasi.

Kepercayaan yang diberikan kepala sekolah kepada para guru dan karyawan mengandung tanggung jawab maka selalu diadakan evaluasi dan supervisi untuk melihat tingkat kegagalan dan keberhasilan tanggung jawab tersebut. Evaluasi dan supervisi yang dilakukan terutama melalui buku refleksi yang selalu dibuat oleh para guru dan karyawan setiap hari. Dari refleksi tersebut dibuat tindakan konkret untuk kemajuan bersama.

Situasi sekolah yang memprihatinkan tidak membuat kepala sekolah menjadi putus asa dan menyerah. Situasi memprihatinkan itu mejadi tantangan bagi kepala sekolah untuk membuat sekolah menjadi lebih baik dan berprestasi. Didorong oleh keyakinan bahwa SD Kanisius harus tetap hidup, maju dan berkembang, kepala sekolah membangun kembali sekolah ini.

Agar sekolah dapat keluar dari masamasa sulit, kepala sekolah mengajak para guru dan karyawan untuk selalu berjuang bersama. Kepala sekolah memotivasi para guru dan karyawan agar memiliki komitmen dan antusiasme yang tinggi dalam bekerja. Untuk itu kepala sekolah menanamkan nilai-nilai kebersamaan, rasa memiliki (handarbeni) dan membangun nama baik sekolah kepada para guru dan karyawan. Para guru dan karyawan diajak untuk bekerja bukan hanya pertama-tama demi finansial melainkan pengabdian dan hadir untuk anak. Komitmen ini menjadi budaya kerja bagi para guru dan karyawan sehingga dalam bekerja para guru dan karyawan dapat saling mendampingi dan membesarkan satu dengan yang lain untuk memajukan sekolah. Komitmen dan motivasi kerja itu juga selalu disegarkan melalui kegiatan-kegiatan rohani seperti refleksi dan rekoleksi.

Kepala sekolah mempunyai cita-cita besar untuk menata kembali SD Kanisius Sengkan yang sedang mengalami masa- 
masa sulit. Menata sekolah bukan hanya secara fisik saja tetapi juga non fisik. Untuk menata kembali sekolah dan keluar dari masa-masa sulit dibutuhkan ide-ide kreatif dan inovatif dari kepala sekolah. Terobosan-terobosan baru mulai dibuat oleh kepala sekolah. Pertama-tama kepala sekolah meningkatkan mutu sumber daya manusia, khususnya guru dan karyawan. Memberikan kesempatan kepada para guru dan karyawan untuk studi lanjut dan mengembangkan kreativitasnya. Selanjutnya kepala sekolah melengkapi sarana dan prasarana agar proses belajar dan mengajar semakin maksimal. Membuka kerja sama dengan pihak lain untuk mendukung peningkatan pelayanan pendidikan. Dan juga memberi perhatian pendidikan bagi anakanak dari keluarga yang tidak mampu.

Selanjutnya agar suasana pembelajaran menjadi nyaman, kepala sekolah juga meningkatkan kesejahteraan guru dan karyawan. Dengan kesejahteraan diperhatikan maka para guru dan karyawan dapat bekerja dengan nyaman. Dan kalau para guru dan karyawan dapat bekerja secara nyaman maka suasana kelas pun menjadi nyaman dan anak-anak akan dapat belajar dengan nyaman pula. Dengan suasana belajar yang nyaman, anak-anak akan lebih mudah diarahkan dan dapat meraih prestasi secara optimal.

Kepala sekolah memberikan perhatian dan penghargaan kepada para guru, karyawan dan para siswa. Perhatian kepala sekolah kepada para guru, karyawan dan siswa berupa kehadiran dan sapaan pribadi. Sementara itu penghargaan yang diberikan kepala sekolah berupa peningkatan honorarium, ucapan terimakasih dan syukur bersama, melibatkan diri dalam setiap kegiatan dan rekreasi bersama. Dengan perhatian dan penghargaan yang diberikan kepala sekolah tersebut para guru merasa diakui keterlibatannya dalam mengembangkan sekolah dan lebih dari itu para guru, karyawan dan para siswa diwongke.

Kepala sekolah sebagai ujung tombak atau pengemudi yang menentukan arah sekolah. Untuk meningkatkan mutu seko- lah, kepala sekolah pertama-tama meningkatkan mutu guru, kemudian meningkatkan mutu pendampingan anak dan menggunakan waktu efektif sekolah semaksimal mungkin. Dan untuk menambah daya tarik sekolah, SD Kanisius Sengkan memberi perhatian yang besar pada pendidikan ekstrakurikuler. Hasil peningkatan mutu sekolah ini sangat dirasakan oleh wali murid yang merasa puas dan sesuai dengan harapannya.

Penelitian implentasi kepemimpinan transformatif kepala sekolah ini dilaksanakan di SD Kanisius Sengkan. Dimensi kepeminpinan transformatif yang diteliti meliputi empat komponen seperti yang dikembangkan oleh Bass dan Riggio (2006: 6-7) yaitu: Idealized influence, Inspirational motivation, Intellectual stimulation, dan Individualized consideration.

Dalam pembahasan ini hasil penelitian dari pertanyaan penelitian no 1 dan 2 dibahas dalam prespektif dimensi idealized influence. Hasil penelitian dari pertanyaan penelitian no 3 dibahas dalam prespektif dimensi inspirational motivation. Hasil penelitian dari pertanyaan penelitian no 4 dibahas dalam prespektif dimensi intellectual stimulation. Dan hasil penelitian dari pertanyaan penelitian no 5 dan 6 dibahas dalam prespektif dimensi individualized consideration. Selanjutnya pembahasan tersebut adalah sebagai berikut:

\section{Dimensi Idealized Influence}

Kepala sekolah menciptakan suasana keterbukaan dalam lingkungan sekolah sehingga masing-masing pribadi bisa saling mengenal satu dengan yang lain. Kepala sekolah mampu mengambil keputusan yang terbaik untuk kepentingan sekolah yang di dasarkan pada pertimbanganpertimbangan nilai yang dipercayainya.

Kepala sekolah membangun rasa percaya diri dan saling percaya antara kepala sekolah dengan para guru dan karyawan. Kepercayaan itu dibangun terutama melalui teladan hidup kepala sekolah sendiri yang dapat dipercaya. Kepala sekolah selalu mengusahakan kesesuaian antara apa yang dikatakan dengan apa 
yang dilakukan. Kepala sekolah juga memiliki keberanian untuk melalukan perubahan demi kemajuan sekolah. Kepala sekolah menjadi agen perubahan (Agents of change). Bahkan kepala sekolah memiliki kepercayaan diri yang kuat dalam menghadapi resiko dari keputusan yang diambilnya.

Untuk membangun kepercayaan dalam diri para guru dan karyawan, kepala sekolah memberikan kesempatan untuk mengeluarkan pendapat, memberikan kesempatan untuk ikut ambil bagian dalam tugas-tugas dan tanggung jawab, dan juga mengikuti pelatihan-pelatihan. Dengan memberikan kepercayaan kepada para guru dan karyawan maka terciptalah suatu relasi dan komunikasi yang akrab. Ralasi antara kepala sekolah dengan para guru dan karyawan bukan pertama-tama relasi antara atasan dan bawahan melainkan terbangun relasi sebagai teman, sahabat yang berjalan bersama untuk meraih prestasi.

Kepercayaan yang diberikan kepala sekolah kepada para guru dan karyawan mengandung tanggung jawab maka selalu diadakan evaluasi dan supervisi untuk melihat tingkat kegagalan dan keberhasilan tanggung jawab tersebut. Evaluasi dan supervisi yang dilakukan terutama melalui buku refleksi yang selalu dibuat oleh para guru dan karyawan setiap hari. Dari refleksi tersebut dibuat tindakan konkret untuk kemajuan bersama.

Hasil penelitian ini sejalan dengan pendapat Aydin Balyer dalam penelitiannya yang berjudul Transformational Leadership Behaviors of School Principals: A Qualitative Research Based on Teachers' Perceptions, melihat kepala sekolah merupakan sosok ideal yang dapat dijadikan panutan bagi guru dan karyawan. Dalam dimensi ini perilaku kepala sekolah dapat menumbuhkan rasa kagum, hormat dan percaya dari orang-orang yang dipimpinnya. "Idealized influence is defined as meeting the needs of others before their own personal needs, avoiding the use of power for personal gain, demonstrating high moral standards, and setting challenging goals for their followers.
Here, managers are exemplary role models for associates. They can be trusted and respected by associate". (diakses tgl 17 Juni 2013 dari http://wwww.iojes.netuserfiles hal. 585)

\section{Dimensi Inspirational Motivation}

Dalam dimensi ini kepala sekolah selalu meberikan tantangan-tantangan baru kepada para guru dan karyawanya untuk semakin berkembang. Kepemimpinan kepala sekolah mampu menginspirasi para guru, karyawan dan siswa untuk meraih prestasi secara optimal. Selain itu kepala sekolah mampu menumbuhkan komitmen dalam diri para guru dan karyawan untuk bekerja dengan antuasias dan optimisme yang tinggi.

Situasi SD Kanisius Sengkan yang memprihatinkan tidak membuat kepala sekolah menjadi putus asa dan menyerah. Situasi memprihatinkan itu mejadi tantangan bagi kepala sekolah untuk membuat sekolah menjadi lebih baik dan berprestasi. Didorong oleh keyakinan bahwa SD Kanisius harus tetap hidup, maju dan berkembang, kepala sekolah membangun kembali sekolah ini. Kepala sekolah berusaha membawa para guru dan karyawan ke arah idealisme yang tinggi. Sekolah tidak asal jalan tetapi mempunyai visi yang harus dicapai dan meyakinkan para guru dan karyawan bahwa cita-cita itu pasti akan tercapai.

Agar sekolah dapat keluar dari masamasa sulit, kepala sekolah mengajak para guru dan karyawan untuk selalu berjuang bersama. Kepala sekolah memotivasi para guru dan karyawan agar memiliki komitmen dan antusiasme yang tinggi dalam bekerja. Untuk itu kepala sekolah menanamkan nilai-nilai kebersamaan, rasa memiliki (sense of belonging) dan rasa bertanggung jawab (sense of responsibility) untuk membangun nama baik sekolah kepada para guru dan karyawan. Para guru dan karyawan diajak untuk bekerja bukan hanya pertama-tama demi finansial melainkan pengabdian dan hadir untuk anak. Komitmen ini menjadi budaya kerja bagi para guru dan karyawan sehingga 
dalam bekerja para guru dan karyawan dapat saling mendampingi dan membesarkan satu dengan yang lain untuk memajukan sekolah dan meraih prestasi yang setinggi-tingginya.

Demikian juga Balyer dalam penelitiannya yang berjudul "Transformational Leadership Behaviors of School Principals: A Qualitative Research Based on Teachers' Perceptions" melihat kepala sekolah dapat memotivasi seluruh guru dan karyawannya untuk memiliki komitmen terhadap visi organisasi dan mendukung semangat team dalam mencapai tujuan-tujuan pendidikan di sekolah. "Inspirational motivation is to motivate and inspire those around them by displaying enthusiasm and optimism, involving the followers in envisioning attractive future states, communicating high expectations, and demonstrating commitment to the shared goals. It describes managers who motivate associates to commit to the vision of the organization. Managers with inspirational motivation encourage team spirit to reach goals". (diakses tgl. 17 Juni 2013 dari http:// www.iojes.netuserfile. Balyer, 2012: 585).

Dimensi Intellectual Stimulation

Kepala sekolah SD Kanisius Sengkan mempunyai cita-cita besar untuk menata kembali sekolah yang sedang mengalami masa-masa sulit. Untuk menata kembali sekolah dan keluar dari masa-masa sulit dibutuhkan ide-ide kreatif dan inovatif dari kepala sekolah. Terobosan-terobosan baru mulai dibuat oleh kepala sekolah. Pertama-tama kepala sekolah meningkatkan mutu sumber daya manusia, khususnya guru dan karyawan. Memberikan kesempatan kepada para guru dan karyawan untuk mengembangkan kreativitasnya. Kepala sekolah mengharapkan agar para guru dan karyawan untuk terus belajar, mengembangkan diri sepanjang hidupnya.

Selanjutnya kepala sekolah melengkapi sarana dan prasarana agar proses belajar dan mengajar semakin maksimal. Membuka kerja sama dengan pihak lain untuk mendukung peningkatan pelayanan pendidikan. Dan juga memberi perhatian pendidikan bagi anak-anak dari keluarga yang tidak mampu. Selanjutnya agar suasana pembelajaran menjadi nyaman, kepala sekolah juga meningkatkan kesejahteraan guru dan karyawan. Dengan kesejahteraan diperhatikan maka para guru dan karyawan dapat bekerja dengan nyaman. Dan kalau para guru dan karyawan dapat bekerja secara nyaman maka suasana kelas pun menjadi nyaman dan anak-anak akan dapat belajar dengan nyaman pula. Dengan suasana belajar yang nyaman, anak-anak akan lebih mudah diarahkan dan dapat meraih prestasi secara optimal.

Balyer dalam penelitiannya yang berjudul "Transformational Leadership Behaviors of School Principals: A Qualitative Research Based on Teachers' Perceptions" melihat kepala sekolah dapat menumbuhkan kreativitas dan inovasi dalam diri para guru dan karyawan dengan mengembangkan pemikiran kritis dan pemecahan masalah untuk menjadikan sekolah ke arah yang lebih baik. "Intellectual stimulation means the leader's consistent effort to stimulate followers to be innovative and creative as well as the leader's effort to encourage followers to question assumptions and to reframe problems and approach them in new ways. Managers with intellectual stimulation promote critical thinking and problem solving to make the organization better". (diakses tgl. 17 Juni 2013 dari http://www.iojes.netuserfile Balyer, 2012: 587)

\section{Dimensi Individualized Consideration}

Dalam melaksanakan kepemimpinannya kepala sekolah SD Kanisius Sengkan memberikan perhatian dan penghargaan kepada para guru, karyawan dan para siswa. Pertahian kepala sekolah kepada para guru, karyawan dan siswa berupa sapaan pribadi, dukungan dan bombongan. Kepala sekolah memberikan perlindungan kepada para guru, karyawan dan para siswa. Menciptakan rasa aman dan nyaman dalam diri para guru, karyawan dan para siswa sehingga proses belajara dan mengajar dapat berjalan dengan baik. 
Kepala sekolah mampu menangkap dan menampung aspirasi dan kebutuhann para guru, karyawan dan para siswa. Salah satu kebutuhan para guru dan karyawan adalah penghargaan atas dedikasinya kepada sekolah. Penghargaan yang diberikan kepala sekolah berupa peningkatan honorarium, ucapan terimakasih dan syukur bersama, melibatkan diri dalam setiap kegiatan dan rekreasi bersama. Dengan perhatian dan penghargaan yang diberikan kepala sekolah tersebut para guru merasa diakui keterlibatannya dalam mengembangkan sekolah dan lebih dari itu para guru, karyawan dan para siswa diwongke. Dan ketika para guru serta karyawan merasa diterima dan diakui keterlibatannya, mereka akhirnya mempunyai dedikasi untuk mengabdi, rasa memiliki dan rasa bertanggungjawab untuk terus memajukan SD Kanisius meraih prestasi yang tinggi.

Hal ini senada dengan yang diungkapkan oleh Balyer dalam penelitiannya yang berjudul "Transformational Leadership Behaviors of School Principals: A Qualitative Research Based on Teachers' Perceptions". Balyer menegaskan; "Individualized consideration represents the leader's consistent effort to treat each individual as a special person and act as a coach and mentor who continually attempts to develop his or her followers' potential. Managers with individual consideration encourage associates to reach goals that help both the associates and the organization". (diakses tgl. 17 Juni 2013 dari http://www.iojes.netuserfile Balyer, 2012: 587)

\section{Simpulan dan Saran}

Simpulan

Penelitian tentang implementasi kepemimpinan transformasional kepala sekolah dalam meningkatkan mutu sekolah di SD Kanisius Sengkan dapat disimpulan sebagai berikut:

Kepala sekolah SD Kanisius Sengkan memiliki nilai-nilai luhur yang diyakini dan diperjuangkan untuk membangun sekolah. Nilai-nilai luhur yang diperjuangkan tersebut meliputi: keyakinan, optimisme, keterbukaan, kedisiplinan, rasa memiliki, kesabaran, kejujuran, dan kenyamanan. Nilai-nilai luhur tersebut tidak hanya difahami melainkan juga dihayati dan diamalkan dalam kehidupan kepala sekolah.

Kepala sekolah SD Kanisius Sengkan membangun rasa saling percaya di antara para guru dan karyawan dengan cara; memberikan teladan melalui cara hidupnya, memberikan kesempatan dan kebebasan untuk berpendapat, memberikan kepercayaan dan tanggung jawab dalam tugas, mengadakan evaluasi dan supervisi. Dengan saling mempercayai maka tumbuh saling menghormati dan menghargai satu dengan yang lain. Kepala sekolah menjadi sosok yang dapat diteladan dan dipercayai oleh para guru, karyawan dan para siswa.

Kepala sekolah SD Kanisius Sengkan membangun motivasi dalam diri para guru dan karyawan dengan cara; menumbuhkan motivasi dalam diri sendiri, berjuang bersama-sama, hadir untuk anak-anak, mengadakan refleksi dan rekoleksi bersama. Keteladanan hidup kepala sekolah dapat menjadi sumber inspirasi bagi para guru, karyawan dan siswa untuk bekerja secara optimal dan antusias.

Kepala sekolah SD Kanisius Sengkan menggali ide-ide kreatif dan inovatif untuk memecahkan masalah yang dihadapi sekolah dengan cara; memberikan peluang dan kebebasan kepada guru dan karyawan untuk berkreasi, meningkatkan mutu sumber daya manusia, melengkapi sarana dan prasarana sekolah, meningkatkan pendampingan siswa, meningkatkan kesejahteraan guru dan karyawan. Dan kepala sekolah selalu memberikan tantangan baru kepada para guru, karyawan dan siswa untuk terus berkembang mencapai prestasi yang optimal.

Kepala sekolah SD Kanisius Sengkan memberikan perhatian dan penghargaan kepada guru, karyawan dan siswa melalui kehadirannya dalam setiap kegiatan sekolah, memberikan apresiasi dan dukungan serta peningkatan honorarium. Kepala 
sekolah memperhatikan dan meningkatkan kesejahteraan para guru dan karyawan.

Kepala sekolah SD Kanisius Sengkan meningkatkan mutu sekolah melalui: peningkatan mutu guru dan karyawan, meningkatkan mutu pendampingan siswa, dan meningkatkan mutu ekstrakurikuler. Kepala sekolah juga membuka kerjasama dengan pihak-pihak lain untuk pengembangan dan peningkatan mutu sekolah.

\section{Saran}

Implementasi kepemimpinan transformasional kepala sekolah SD Kanisius Sengkan secara umum sudah baik. Kepala sekolah telah mampu membawa perubahan ke arah yang lebih baik. Kepala sekolah juga telah mampu membentuk budaya kerja yang dijiwai oleh semangat kerjasama dan pengabdian. Namun ada beberapa hal yang perlu diperhatikan oleh kepala sekolah agar apa yang telah dicapai saat ini terus dapat dikembangkan.

Beberapa hal yang dapat menjadi saran antara lain:

Kepala sekolah perlu melakukan regenerasi untuk mempersiapkan kepemimpinan berikutnya agar tidak terjadi krisis kepemimpinan lagi.

Kepala sekolah hendaknya terus berusaha menanamkan nilai-nilai Kanisius kepada para guru, karyawan dan siswa agar outcome yang dihasilkan mempunyai karakter baik.

Kepala sekolah perlu terus memberikan tantangan-tantangan baru kepada para guru, karyawan dan siswa agar prestasi sekolah tetap dapat dipertahankan.

Kepala sekolah perlu terus mengusahakan kualitas ekstrakurikuler sebagai salah satu daya tarik sekolah.

Melihat semakin banyaknya orang tua yang berminat meyekolahkan anaknya di SD Kanisius Sengkan kepala sekolah hendaknya terus mengusahakan peningkatan mutu guru.

Kepala sekolah bisa membuka kerjasama dengan pihak lain, khususnya para alumni untuk meningkatkan mutu sekolah yang berkelanjutan.
Kepemimpinan memegang peranan yang sangat penting dalam sebuah organisasi, termasuk dalam bidang pendidikan. Kepemimpinan sangat berperan dalam mengusahakan perubahan ke arah yang lebih baik. Salah satu model kepemimpinan yang dapat berperan dalam mengusahakan perubahan adalah kepemimpinan transformasional.

Berdasarkan kesimpulan dari penelitian tentang implementasi kepemimpinan transformasional kepala sekolah SD Kanisius Sengkan, kepala sekolah sangat berperan dalam mengusahakan perubahan ke arah yang lebih baik. Kepala sekolah memiliki keberanian untuk melakukan perubaham menuju tingkat prestasi yang lebih tinggi. Keberanian itu tumbuh dari keyakinan akan nilai-nilai luhur yang dihayatinya. Kepala sekolah juga mampu membangkitkan semangat kerjasama, disiplin dan motivasi para guru, karyawan dan siswa untuk bekerja secara optimal. Kepala sekolah mampu membangun kesadaran berorganisasi dengan cara menumbuhkan rasa memiliki (sense of belonging) dan rasa bertanggung jawab (sense of responsibility) dalam diri para guru, karyawan dan siswa serta membangun kemauan atau antusiasme yang kuat untuk meraih prestasi setinggi-tingginya.

Kepemimpinan transformasional merupakan salah satu model kepemimpinan yang dapat menciptakan perubahan. Dengan demikian kepemimpinan transformasional diharapkan dapat menjadi solusi untuk mengatasi krisis kepemimpinan yang terjadi, khususnya kepemimpinan dibidang pendidikan. Namun kepemimpinan transformasional tetap memiliki kekurangan, yaitu sangat tergantung dari pribadi pemimpin. Kepemimpinan transfomasional akan sangat efektif bila dijalankan oleh seorang pribadi yang kuat, pribadi yang memiliki nilai-nilai luhur yang dihayati dan memiliki visi yang jelas tentang kepemimpinan. 


\section{Daftar Pustaka}

Balyer. A. (2012). Transformational leadership behavior of school principals a qualitative research based on teachers' perception. diakses tgl 17 Juni 2013 dari http://www.iojes.netuserfile. hal. 586-587.

Bass, B. M \& Ronald E. R. (2006). Transformational leadership (2 ed). Mahwah, New Jersey: Lawrence Erlbaum Associate Publishers.

Departemen Tenaga Kerja. (1986). Peningkatan mutu terpadu. Jakarta: Pusat Produktivitas Nasional.

Depdiknas. (2002). Manajemen berbasis sekolah untuk sekolah dasar. Jakarta: Depdiknas, Direktorat Jenderal Pendidikan Dasar dan Menengah.

Fatchul Mu'in. (2011). Pendidikan karakter, konstruksi teori dan prakatik. Yogyakarta: AR-Ruzz Madia.

Husaini Usman. (2008). Manajemen; teori, praktik $\mathcal{E}$ riset pendidikan, ed 2 . Jakarta: Bumi Aksara.

Miles, M. B. \& Huberman A. M. (1994). Quantitative data analisis ed 2. London: Sage Publication.

Mulyasa. (2011). Manajemen berbasis sekolah; konsep, strategi dan implementasi. Bandung: PT Remaja Rosdakarya.

(2009). Menjadi kepala sekolah profesional. Bandung: PT Remaja Rosdakarya.

(2011). Manajemen $\mathcal{E}$ kepemimpinan kepala sekolah. Bandung: PT Remaja Rosadakarya.
Sadler, P. (1997). Leadership. London: Kogan Page Limited.

Sergiovanni, T. J. (1991). The principalship a reflective practice perspective. 2.ed. Boston: Allyn and Bacon A Devision of Simon \& Schuster. Inc.

Simic. I. (1999). Tranfomational leadershipthe key to successful management of transformational organizational changes. Faculty of economics, university of Nis. Udc 65.012.3. diambil pada tanggal 25 Mei 2013 dari http:/ / facta.junis.ni.ac.rs/.

Starratt, R. J. (2007). Menghadirkan pemimpin visioner, kiat menegaskan peran sekolah. Yogyakarta: Kanisius.

UU No 22 tahun 1999 tentang Otonomi Pemerintah Daerah.

UU No 25 tahun 1999 tentang Perimbangan Keuangan antara Pemerintah Daerah dan Pusat.

Wahjosumidjo. (2011). Kepemimpinan kepala sekolah, tinjauan teori dan permasalahannya. Jakarta: PT Raja Grafindo Persada.

Wuradji. (2009). The educational leadership, kepemimpinan transformatif. Yogyakarta: Gama Media.

Yayasan Pendidikan Kanisius. (2010). Buku kenangan 20 tahun tk dan 40 tahun sd kanisius sengkan; menggapai cita-cita dalam keterbatasan.

Yayasan Pendidikan Kanisius. (2011). Rencana kerja sd kanisius sengkan tahun pelajaran 2011 - 2012 s/d tahun pelajaran $2014-2015$. 